\title{
STUDY OF FINGERPRINT PATTERNS IN RELATIONSHIP WITH BLOOD GROUP AND GENDER IN SAURASHTRAREGION
}

\section{Urvik Kukadiya ${ }^{1}$, Pratik Trivedi ${ }^{2}$, Ashish Rathva ${ }^{* 3}$, Chintan Lakhani ${ }^{4}$.}

${ }^{1}$ Assistant Professor, Department of Anatomy, GMERSMedical College, Junagadh, India.

${ }^{2}$ Tutor, Department of Anatomy, GMERS Medical College, Junagadh, India.

${ }^{3}$ Assistant Professor, Department of Anatomy, GMERS Medical College, Junagadh, India.

${ }^{4}$ Tutor, Department of Anatomy, GMERS Medical College, Junagadh, India.

\section{ABSTRACT}

Finger prints are considered as the best tool of identification of person. Finger print evidence is by far the most effective and reliableevidence in the court of law. Two major aspects which prove the efficiency of finger prints are, the ridges formed during thefetal period do not change their course of alignment throughout the life of an individual until the skin is decomposed andthe other one is two finger prints of either a same individual or two different individuals are never alike, they differ in theirpatterns and ridge characteristics. Due to this unique attribute of finger print, it is widely considered asconclusive evidence in the court of law.

We have carried out a study including 150 medical students of GMERS Medical College Junagadh, Gujarat, among which 75 were male and 75 werefemale subjects having different $A B O$ blood groups belonging to different age groups.All the 10 fingerprint patterns were divided into Loops, Whorls and Arches. Results indicating thatLoops are most commonly found fingerprint patterns while, Arches are least common. Loops dominated in all the Blood groupsof both $\mathrm{Rh}^{+v e}$ and $\mathrm{Rh}^{\text {-ve }}$ negative individuals whereas, Whorls were found to be dominating in only $\mathrm{O}^{\text {-ve }}$ blood group. The onlycorrelation between gender and finger print patterns in this study is that, Loops and Arches were found in higher frequencyin Females compared to Males and whorls were found to be high in males compared to females.

KEYWORDS: Association, fingerprints, blood groups, patterns.

Corresponding Author: Dr. Ashish Rathva, Assistant Professor, Department of Anatomy, GMERS Medical College,Junagadh, India. Mobile No.: 8758898589/8160044060

E-Mail: aashish.rathwa60@gmail.com

Access this Article online

Quick Response code

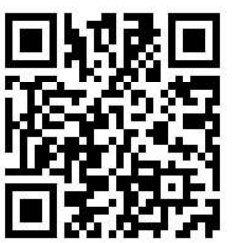

DOI: $10.16965 /$ ijar.2020.159

Journal Information

International Journal of Anatomy and Research

RG Journal ISSN (E) 2321-4287 | ISSN (P) 2321-8967

https://www.ijmhr.org/ijar.htm

DOI-Prefix: https://dx.doi.org/10.16965/ijar

Article Information

Received: 27 Apr 2020

Peer Review: 27 Apr 2020

Revised: None
Accepted: 15 May 2020

Published (O): 05 Jun 2020

Published (P): 05 Jun 2020

\section{INTRODUCTION}

The skin covers the anterior surface of human hand and plantersurface of the human foot is different in the texture andappearance than the one which it covers the rest of the humanbody. This skin on the palmar and planter surface iscontinuously wrinkled with narrow minute ridges known asfriction ridges.A finger print is an impression of the frictionRidges on all parts
(Figure-1).The dermal carvings or finger prints appearfirst on the human fingers, palm, soles and toesfrom $12^{\text {th }}$ to $16^{\text {th }}$ week of embryonic development and their formation gets completed by the $14^{\text {th }}$ week i.e. about the $6^{\text {th }}$ fetal month. The ridges thus, formed during the fetal perioddo not change their course or alignment throughout the life of anindividual, until destroyed by decomposition of the skin afterdeath [1]. 
Various physical evidences used for identification of individualsincludes fingerprints, DNA profiling, lip marks, foot prints, bite marks etc.Fingerprints are highly conserve,constant and individualistic evidence represent the mostreliable criteria for confirm identification.S Finger prints follow theLocard's Principle of Exchange.Fingerprints are now a day used in manyof the offices, educational institutions to validate the presence ofan individual [2].

Fig. 1: A unique hand finger print showing three distinct patterns.

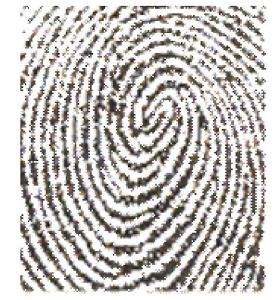

Whorl Pattem

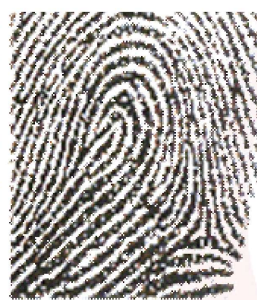

Leep Patrern

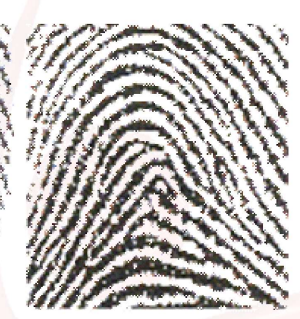

Arrot Paitern
Blood group system was discovered way back in 1901 by KarlLandsteiner. Till date, 19 major groups have been identified whichvary in their frequency of distribution amongst various races ofmankind. Clinically, only 'ABO' and 'Rhesus' groups are ofmajor importance.

'ABO' system is further classified as $A, B, A B$ and $O$ blood group types on the basis of corresponding antigen in plasma. 'Rhesus' system is classifiedinto ' $\mathrm{R} \mathrm{h}^{\text {+ve' }}$ and ' $\mathrm{Rh} \mathrm{h}^{-\mathrm{ve} \text { ' }}$ according to the presence or absenceof ' $D$ ' antigen [3].

Here in this research paper we aspire to find a unique co-relationship between fingerprint pattern, blood group and gender in population within Saurashtraregion, Gujarat.

\section{MATERIALS AND METHODS}

The present study was carried out in GMERS Medical College Junagadh, Gujarat. 150 medical students of this college of various age groups were participated in the studyvoluntarily and their finger prints were collected.The fingerprints were taken using Camel quick drying duplicating ink. The smeared palm and fingers of both handswere printed on a durable plain paper laid down on a pressurepad which consisted of ten different blocks for ten fingers ofright hand and left hand respectively. Both rolled and planeprints of right and left hand were taken (Figure-2). After obtaining thefinger prints the basic details of an individual such as name, age and sex was also recorded. Primary patterns (loops, whorl and arches) wereobserved with the help of a powerful hand lens. Blood groups ofall the persons were also noted for further study. Each finger in the finger print slip was assigned a number in well mannered way. For instant, the $1^{\text {st }}$ number was given to the right hand thumb and $10^{\text {th }}$ number to left hand little.

Fig. 2: Laboratory equipment and materials used to collect fingerprinting patterns of individual.

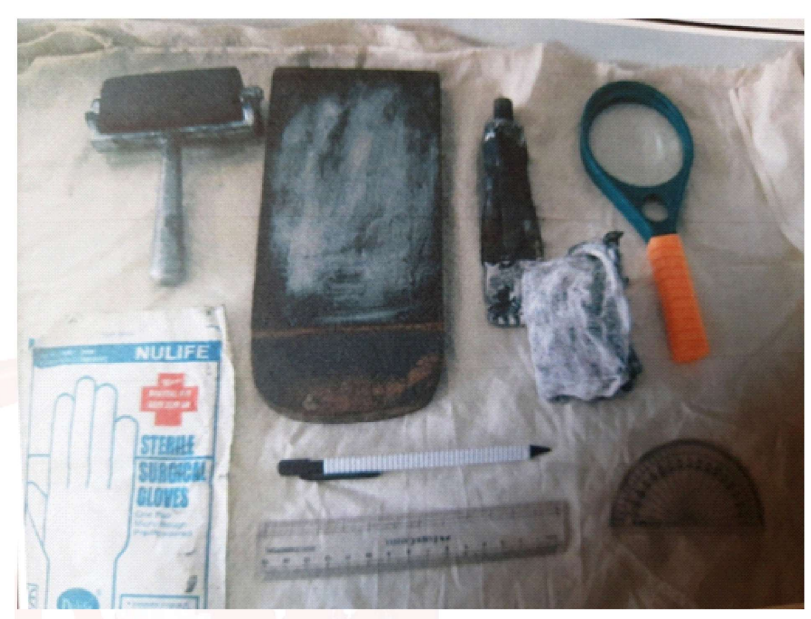

\section{RESULTS AND DISCUSSION}

Table1:Distribution of Blood Groups according to Gender.

\begin{tabular}{|c|c|c|c|}
\hline Blood Group & Male & Female & Total \\
\hline A & $17(11 \%)$ & $15(10 \%)$ & $32(21 \%)$ \\
\hline B & $27(17.5 \%)$ & $28(19.5 \%)$ & $55(37 \%)$ \\
\hline AB & $5(3.5 \%)$ & $5(3.5 \%)$ & $10(7 \%)$ \\
\hline O & $27(18 \%)$ & $26(18 \%)$ & $53(35 \%)$ \\
\hline Total & 75 & 75 & 150 \\
\hline
\end{tabular}

Table-1 shows distribution of blood groups in respect toGender. Majority of the subjects belonged to the blood group $B$ i.e. $55(37 \%)$ followed by $0 ; 53(35 \%), A ; 32(21 \%)$ and $A B ; 10$ (7\%). Blood group $B$ was predominantly found in females but inmales both $B$ and $O$ were equally distributed.

Table2:Distribution of subjects according to Rh factor oftheir Blood GROUP.

\begin{tabular}{|c|c|c|}
\hline Blood Group & Rh- Positive & Rh- Negative \\
\hline A & $29(19.5 \%)$ & $3(1.5 \%)$ \\
\hline B & $53(35 \%)$ & $2(1 \%)$ \\
\hline AB & $10(6.5 \%)$ & $0(0 \%)$ \\
\hline O & $52(34 \%)$ & $1(0.5 \%)$ \\
\hline TOTAL & $144(97 \%)$ & $6(3 \%)$ \\
\hline
\end{tabular}

In this table,144 among 150 subjects belonged to $\mathrm{Rh}^{\text {+ve }}$ whereas, 6 of150 subjectswere $\mathrm{Rh}^{\text {-ve }}$. Outof $144 \mathrm{Rh}^{+\mathrm{ve}}$ subjects majority of thesubjects, 
53 (35\%) belonged to blood group B, 52 (34\%) belonged to $0,29(19.5 \%)$ belonged to $A$ andonly $10(6.5 \%)$ belonged to blood group AB.Similarly among $6 \mathrm{Rh}^{\text {-ve }}$ subjects, 3 (1.5\%) belonged to $\mathrm{A}$, $2(1 \%)$ to $B, 1(0.5 \%)$ to $O$ and no any individual found to belonged with blood group $A B$. The percentage ofR $\mathrm{h}^{\text {-ve }}$ subjectswas generally less in the study.

Table3:Distribution of Primary Finger print patterns of all the fingers in both the hands

\begin{tabular}{|c|c|c|}
\hline $\begin{array}{c}\text { Fingerprint } \\
\text { Atterns }\end{array}$ & $\begin{array}{c}\text { Total } \\
\text { Number }\end{array}$ & Percentage\% \\
\hline Loops & 844 & $56.50 \%$ \\
\hline Whorls & 444 & $29.60 \%$ \\
\hline Aarches & 173 & $11.50 \%$ \\
\hline Total & 1500 & $100 \%$ \\
\hline
\end{tabular}

Table-3 shows distribution offinger print patterns of all thefingers in both the hands. Total no of loops found in all the digits were 844 (58.9\%). Similarly numbers of whorls in all of both the hands were 444 (29.6\%) and numbers of archeswere 173 (11.5\%). This table clearly indicates that Loops weremore common finger pattern found than the whorls and arches. Finger print pattern were recorded as per figure 3 .
Fig. 3: Finger print pattern of right and left hand.

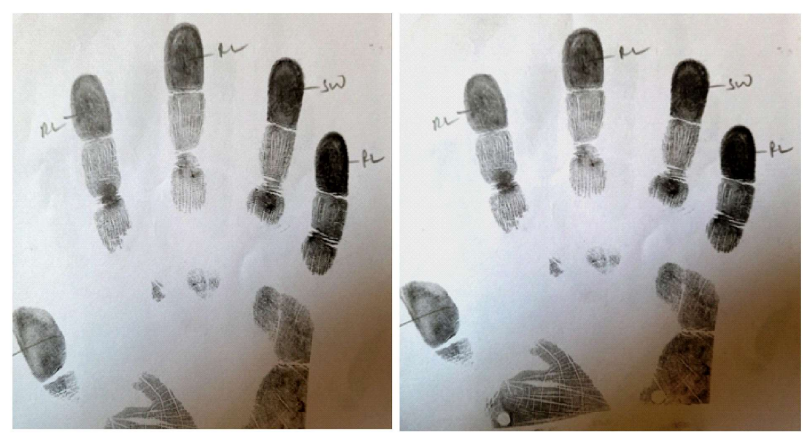

Table4:The number of the finger print patterns amongMales and Females.

\begin{tabular}{|c|c|c|c|c|}
\hline $\begin{array}{c}\text { Fingerprint } \\
\text { patterns }\end{array}$ & \multicolumn{2}{|c|}{ Male } & \multicolumn{2}{c|}{ Female } \\
\hline Loops & 400 & $47.38 \%$ & 444 & $52.63 \%$ \\
\hline Whorls & 254 & $57.09 \%$ & 191 & $42.90 \%$ \\
\hline Arches & 83 & $48.26 \%$ & 90 & $51.73 \%$ \\
\hline
\end{tabular}

Table-4shows the distribution of finger print patterns withinboth the genders. Frequency of Loops were found to be higher in females; 444(52.63\%) and whorls were found to be higher in males; 254 (57.09\%). Arches were found more in females;90 (51.73\%) as compared to males; 83 (48.26\%).

Table5:Distribution of Fingerprint Patterns among A, B, AB, O blood groups with Rh factors.

\begin{tabular}{|c|c|c|c|c|c|c|c|c|}
\hline \multirow{2}{*}{ Type of pattern } & \multicolumn{2}{|c|}{ Blood group A } & \multicolumn{2}{c|}{ Blood group B } & \multicolumn{2}{c|}{ Blood group AB } & \multicolumn{2}{c|}{ Blood group O } \\
\cline { 2 - 10 } & $\mathbf{R h}+$ & $\mathbf{R h}-$ & $\mathbf{R h}+$ & $\mathbf{R h}-$ & $\mathbf{R h}+$ & $\mathbf{R h}-$ & $\mathbf{R h}+$ & $\mathbf{R h}-$ \\
\hline Total loop & 168 & 18 & 316 & 14 & 60 & 0 & 307 & 2 \\
\hline Percentage & 57.94 & 60 & 59.57 & 67.5 & 60.76 & 0 & 59.11 & 20 \\
\hline Total whorls & 91 & 8 & 147 & 4 & 38 & 0 & 148 & 7 \\
\hline Percentage & 31.28 & 26.67 & 27.71 & 17.5 & 37.6 & 0 & 28.52 & 70 \\
\hline Total arches & 31 & 4 & 67 & 2 & 2 & 0 & 64 & 1 \\
\hline Percentage & 26.67 & 13.34 & 12.71 & 15 & 1.53 & 0 & 12.35 & 10 \\
\hline Total & 290 & 30 & 530 & 20 & 100 & 0 & 520 & 10 \\
\hline
\end{tabular}

Table-5showsthedistribution of the finger printpatternsamong $A B O$ blood groups of all the subjects. More numbersofloops were found in blood group B i. e. $59.57 \%$ followed by $O$ i.e. 59.11\% among the $\mathrm{Rh}^{\text {+ve }}$ individuals. Whereas, the prevalence ofwhorl predominantly found in the blood group $\mathrm{O}$ within $\mathrm{Rh}^{\text {-veindividuals. Whorls }}$ in $\mathrm{Rh}^{\text {+ve }}$ individuals were equally dominantin both B and Oblood groups; Arches were least commonly found in all the blood groups. Least numbers ofarches were seen in the blood group $A B$ and more number in $B$.

\section{DISCUSSION}

The present study is an approach to further classify finger printpatterns. These patterns fall into three general classes calledArches, Loops, and Whorls. Arches are the simplest patternsand also the rarest. There are two types: plain arches and tented arches.

Loops are designatedas being either radial or ulnar, depending on which side of thefinger the lines enter. The loop is the most common of all thepatterns. There are four different whorl 
patterns: the plainwhorl, the central pocket loop, the double loop, and theaccidental whorl. The accidental whorl can be any pattern orcombination of patterns that does not fit into any of the aboveclassifications. The term "Compo-site" is used to describe suchspatterns. Positive identification using fingerprints can beestablished only if 16 to 20 points of similarity exist in theminutiae [4].

This study was an approach to associate finger prints, bloodgroups and gender. Blood group $B$ was predominantly foundamong the subjects followed by $O$. The distribution of primaryfinger prints among the subjects was high frequency of loopsmoderate of whorls and low of arches.

Bharadwaja et al [2]conducted a study during 2000-2001 on 300 medical studentswith different $A B O$ blood groups in Rajasthan which revealedthat individuals with blood group $A$ have more of loops, whilethat of blood group $A B$ had more of whorls.

Similarly, Rastogi and Pillai [5]also conducted astudy among 200 medical students of Kasturba MedicalCollege, Mangalore which showed that blood group A hadhigher frequency of Loops and blood group $\mathrm{O}$ had higherfrequency of whorls and arches were found to be high in bloodgroup A [5]. Results of the present study differ comparatively.

\section{CONCLUSION}

Present study is an attempt to analyze and correlate fingerprintpatterns with gender and blood group of an individual. Althoughwe know that finger prints are never alike and they neverchange from birth till death, this study is an attempt made by usto associate finger prints with gender and blood group of anindividual which may in turn enhance the authenticity of thefingerprints in identification and detection of criminals ${ }^{6}$.From the above study the following results were found:
1. Loopsare the most commonly found fingerprint pattern and Archesaretheleastcommon.

2. Blood group B positive is the mostcommon and $O$ negative and $A B$ negative is the rarest.

3. Morenumber of whorls were found in $\mathrm{O}$ ${ }^{\text {ve compared to otherRh }}{ }^{-v e}$ blood groups which is consistence with observation of Dr.Rastogiand Pillai ${ }^{5}$ and Kanchan and Chattopadhyay ${ }^{7}$.

4. Loops and arches were common inBlood group $B$ and $O$.

5. Blood group $\mathrm{B}^{\text {tve }}$ and $\mathrm{O}^{\text {tve }}$ equally hadhighest number of whorls.

6. Least arches seen in Blood groupAB.

7. Loops and Arches were highest in Females and Whorlshighest in Males.

8. Highest numbers of Loops were found in blood groups $B$ and $O$ compared to $A$ and $A B$.

\section{Conflicts of Interests: None}

\section{REFERENCES}

[1]. Surinder Nath, Finger Print Identification, Gita Press, Delhi, 1984,1-15.

[2]. Bharadwaja A., Saraswat P.K., Agrawal S.K., Banerji $P$. andBharadwaj S. Pattern of fingerprints in different $A B O$ bloodgroups, Journal of Forensic medicine \& Toxicology, 2004;21(2):49-52.

[3]. Bijlani R.L., Textbook of Physiology, 2nd ed. Blood Groups, $93-94$.

[4]. Subrahmanyam B.V., In: Modi_s Medical Jurisprudence andToxicology, 22nd ed. New Delhi: Butterworths India, 1999,71-77.

[5]. Dr. Prateek. Rastogi, Ms. Keerthi. R. Pillai, A study of Fingerprints in Relation to Gender and Blood Group, Journal ofIndian Academy of Forensic Medicine, 2010;32(1):11-14.

[6]. Pillay V.V., Textbook of Forensic Medicine and Toxicology,15th ed. Hyderabad: Paras Medical Publishers 2009, 53-94.

[7]. Kanchan T. and Chattopadhyay S., Distribution of FingerprintPatterns among Medical Students, Journal of Indian Academyof Forensic Medicine, 2006;28(2):65-68.

How to cite this article:

Urvik Kukadiya, Pratik Trivedi, Ashish Rathva, Chintan Lakhani. STUDY OF FINGERPRINT PATTERNS IN RELATIONSHIP WITH BLOOD GROUP AND GENDER IN SAURASHTRAREGION. Int J Anat Res 2020;8(2.3):7564-7567. DOI: 10.16965/ijar.2020.159 